\title{
PEDAGOGICAL FACTORS OF DEVELOPMENT OF CREATIVE COOPERATION SKILLS THROUGH VERTIC INTEGRATION OF STUDENTS OF HIGHER TECHNICAL EDUCATION
}

\author{
Davron Umaralievich Jarkinov
}

Phd Student Andijan State University, Uzbekistan

\section{ABSTRACT}

The article analyzes the pedagogical factors of developing creative collaboration skills of students of higher technical education through vertical integration.

KEYWORDS:- Vertical, integration, heritage, education, creative collaboration,

\section{INTRODUCTION}

Incomplete adherence to the principle of pedagogical priority of developing creative collaboration skills through the vertical integration of students of higher technical education in higher and secondary special education institutions creates certain problems in education. The content and organization of pedagogical education for the development of creative collaboration skills of students of higher technical education through vertical integration remains mainly to provide students with theoretical knowledge. The educational process consists of the mutual integration of developing educational situations. In it, the creative collaboration of professionals is a process of vertical integration. In the process of purposeful formation of personnel, not only management, but also interactions aimed at achieving the set goal are carried out. The success of the educational process depends on many factors, a number of situations, the interaction of personnel, as well as the rules that apply when organizing their communication. Dialogues are an integral part of the work of students of higher technical education, specialists. It requires a specialist to know the basics of professional activity, to be able to manage the activity and his mental state, to have the skills to organize communication.

\section{Materials AND METhods}

Interdisciplinary links in the educational process, the laws and trends of formation and development of integration, problems of preparation of future specialists for professional activity on the basis of integrative education and 
theoretical, conceptual and technological bases of pedagogical diagnostics of professional training R.H.Djuraev, A.R.Khodjabaev, U.I. Inoyatov, N.A.Muslimov, Q.T.Olimov, E.0.Turdikulov, M.B.Urazova, J.A.Hamidov, M.Toshov, O.A.Abduquddusov, M.Jumaniyozova, R.A. In the works of Mavlonova and etc.

\section{Results AND DISCUSSION}

Full formation and all-round development of the person, understanding of national identity in the study of the pedagogical heritage of Eastern thinkers, education of spiritual and moral qualities in the person, formation of spiritual and moral qualities of the person in mastering the basics of professional and pedagogical dialogue. In the course of the research it was found that the study of theoretical and practical knowledge of students in the field of higher technical education by specialists on strengthening the educational potential of education is based on a number of factors. In our view, it is important to strengthen the creative potential of education in the educational process, and the following will play a leading role:

- Ensuring the cooperation of teachers and students to achieve the goal;

- The duration of the learning process (in this process, the student is constantly under the influence of various situations, in which case he increases a certain personal experience);

- The complexity of the educational process in accordance with the psychological and pedagogical requirements, the establishment of relationships between the subjects of education. In-depth knowledge on training future professionals will be required. Information-research reports use methods such as reporting, highlighting, persuading, explaining, justifying, narrating, narrating, systematizing, describing, generalizing, concluding, concluding. Mutual creative cooperation, professional and pedagogical dialogues based on the ideas of humanity contribute to the individual and creative development of the participants. In this situation, the actions of future professionals are regulated, an emotionally-positive environment is created, their emotionalpsychological unity is ensured, and good relationships are established for them to work together. All this is an important basis for influencing the creative activity of the staff, as well as a positive impact on their active communication. In professional communication in the field of education, it is necessary to manage, taking into account the life activities and age of professionals. Purposeful organization of dialogues between students of higher technical education in educational work contributes to the formation of humane relations. Leads to meaningful relationships with others increases the effectiveness of personality formation and development. Active life positions of future economists are formed in educational institutions. How to have an effective educational impact in the process of creative collaboration? To achieve this goal, the following conditions must be met:

- be able to arouse the interest of future professionals in the study of the topic in the process of communication;

- the use of interesting, meaningful, educational materials in this period;

- elimination of negative habits based on the positive qualities of future professionals;

- Achieving logical, literate, appropriate questions;

- ability to listen to the interlocutor, to show respect for him, to achieve stability of attention, politeness, curiosity;

- mutual understanding, mutual interest, care, 
CURRENT RESEARCH JOURNAL OF PEDAGOGICS 2(6): 32-37, June 2021

DOI: https://doi.org/10.37547/pedagogics-crjp-02-06-08

ISSN 2767-3278

(C)2021 Master Journals

\section{Crossref do) 81 Google}

Accepted 11 $11^{\text {th }}$ Une, 2021 \& Published $16^{\text {th }}$ June, 2021

\begin{abstract}
organization of cooperation-based
interactions, interaction;
\end{abstract}

- Achieving emotional unity in the process of cooperation. Observations show that the teachers of the college, taking into account the basics of professional-pedagogical dialogue, succeed in carrying out direct educational work.

In the current context, the educational process is a process based on mutual cooperation and exchange of creative experience. The introduction of new forms of teaching in several types of education is crucial in achieving the organization of effective teaching in education. The more the acquired knowledge and skills form an associative connection with the available information in practice, the easier it will be to assimilate and store in memory. In this sense, the application of effective teaching methods introduced in higher education provides ample opportunities for students to grow their scientific creativity, increase independent intellectual analysis and work on themselves. Today's innovations in the field of education require an increase in the independent activity of future professionals, a greater approach to non-traditional methods of teaching. Independent learning tasks, problemsolving forms of problem-solving, and teaching materials based on audiovisual tools have a strong socializing effect on the personal development of future professionals. It is through such teaching methods that it is possible to prepare future professionals for higher education, to form logical and critical thinking, to reveal their existing abilities. This will be a pedagogical activity that requires spontaneous teacher-student cooperation. The educator is usually able to equip the student with new knowledge only if he or she is aware of how well the students have mastered the learning information during the teaching process. Accordingly, the educator aims to teach the student to understand, assimilate and apply the educational information, the content of the information. This is commonly referred to as a learning objective. After all, it is a description of the expected outcome at the end of the learning process. Since the learning process takes place in the presence of two living beings, the educator realizes the purpose of teaching, the student the goal of learning. In general, effective methods in education, conscious goal-based approaches ensure the full development of the individual. Having an independent mind, being able to analyze reality correctly, and expressing a conscious attitude are important improvements in the formation of a harmonious personality.

\section{Conclusion}

The modern education system requires further improvement of mechanisms for cultivating the creative and professional abilities of future professionals on the basis of creative approaches and an innovative system of their implementation in practice. In this regard, the creation of educational innovations in the field of education, the creation of intellectual resources of socio-economic development through the development of cognitive thinking skills on the basis of modern pedagogical processes that create new knowledge and expand opportunities for training competitive personnel. Today, it is time for everyone to understand the world, to understand the laws of life and society, to think critically in order to know the worldviews, ideas and professions of different peoples and nations on earth. After all, in today's world, everyone needs to be able to think critically in order to argue with any opponent and dissident. The importance of research-based activities is to receive information on a community basis, to express their attitude to it, to look for mistakes and inconsistencies, to try not to make mistakes in their judgments, to understand their misunderstandings, to think, to draw clear 
CURRENT RESEARCH JOURNAL OF PEDAGOGICS 2(6): 32-37, June 2021

DOI: https://doi.org/10.37547/pedagogics-crjp-02-06-08

ISSN 2767-3278

(C)2021 Master Journals

\section{Crossref do) 81 Google}

Accepted 11 $11^{\text {th }}$ Une, 2021 \& Published $16^{\text {th }}$ June, 2021

conclusions. The task of education today is to teach students to act independently in the growing information-educational environment, to use the flow of information rationally through conscious thinking. The creative activity of students is a process of developing new knowledge, a type of cognitive activity. It is characterized by objectivity, reliability, accuracy. It is understood to determine the topic, to analyze the existing information, conditions and methods in the field of research, scientific hypotheses, experiments, analysis and generalization of the results, to verify the hypotheses, to express new facts and laws, to make scientific predictions. Creative activity is a complex process such as the combination of ideas and opportunities, the development of new knowledge, the rethinking and reconstruction of concepts and information. It is also a process that takes place simultaneously on several levels of active and interactive cognition. Each doctrine has its own theoretical and practical basis. From the time when the first ideas on strategies for the development of creative activity were put forward, along with its theoretical foundations, the general basis for its application in practice began to be created. Strategies that develop creative activity form the theoretical and practical basis of its purpose, object, basic concepts, criteria, and so on. In order to talk about the general essence of strategies that develop students' creative activity, it is first necessary to understand the essence of this concept. There are many definitions of the concept of critical developmental strategies available today, so that each teacher can adopt or define his or her own definition of what is most appropriate for him or her based on the literature and practical experience he or she has learned. In the process of studying modern didactics in the study of students' critical thinking in the use of strategies that develop their creative activity in the teaching process, they make extensive use of the achievements of research-oriented educational psychology. Depending on the age and content of the educational material, the specificity of this activity establishes psychological laws in the educational process, considers the individual and typical characteristics of students in the process of creative activity. Analytical-synthetic activity, as well as intellectual operations such as comparison, abstraction, generalization and clarification play an important role in the process of assimilation. The joint (group) activity, cooperation of the future profession, as well as the accepted methods of professional communication in this profession and social responsibility for the results of their work are considered social knowledge, and the role of the case method in its formation in economic education is unique. This method helps students of higher technical education to acquire group views on the situation, the main problems and ways to solve them, to feel responsible for the most optimal decisions they make, and to activate their mental field. It is also recognized in science that the acquisition of methods of personal expression and self-development, as well as the means of resisting his professional "distortion (deformation)" is recognized as personal knowledge, and the role of educational films in its formation is invaluable. Using this method, the characteristics of the future professional's self-awareness, the ability to correctly assess his good and bad qualities, the ability to internally control his right or wrong actions are formed. Having such knowledge accelerates the process of "professional selfawareness" in students of higher technical education and reveals the essence of "professional mentality". When studying the issue of personality in the context of vocational education and professional knowledge, it is possible to recognize that in the conditions of change a person who does not have a clear idea 
CURRENT RESEARCH JOURNAL OF PEDAGOGICS 2(6): 32-37, June 2021

DOI: https://doi.org/10.37547/pedagogics-crjp-02-06-08

ISSN 2767-3278

(C)2021 Master Journals

\section{Crossref do) 81 Google}

Accepted 11 thJune, 2021 \& Published $16^{\text {th }}$ June, 2021

of himself, does not know his capabilities and abilities can be a little lame not only in life but also in belief. Many young people studying in the field of vocational education (socio-economic sphere) have a misconception about their abilities and abilities. Improving professional knowledge, which serves to overcome such perceptions, and ultimately the formation of motivation among students to be committed to their profession and mastery, will also be the basis for preventing some of the inconveniences encountered in practice.

\section{ReFERENCES}

1. Джураев P.X. Организационнопедагогические основы интенсификации системы профессиональной подготовки в учебных заведениях профессионального образования: Автореф. дисс...док.пед.наук.- Т.:1995.$43 \mathrm{c}$;

2. Ходжабоев А.Р. Учебно-методический комплекс подготовки учителей трудового обучения.Метод. реком.Т.:,УзНИИПИ,1989. -93с.;

3. Иноятов У.И. Теоретические и организационно-методические основы управления контроля качества образования в профессиональном колледже. Дисс. ... докт. пед. наук. Ташкент, 2003. - 327 с.;

4. 4. Muslimov N.A. Theoretical and methodological bases of professional formation of a teacher of vocational education. Diss. .. ped. Sc. d. - T.: 2007. $315 \mathrm{p}$.;

5. 5. Olimov Q.T. Theoretical and methodological bases of creating a new generation of educational literature in special disciplines: Dis. ... Ped.Sc. doct. -
Tashkent: 2005. - 286 p .;

6. Турдикулов Э.О., Джураев Р.Х. ва бошқалар. Интеграциялашган таълим назарияси ва амалиёти. - Тошкент: Сано-стандарт, 2009. - 176 б.;

7. Ўрозова М.Б. Бўлажак касбий таълим педагогини лойихалаш фаолиятига тайёрлаш технологиясини такомиллаштириш. пед. фан.докт. дисс.... автореф. - Тошкент: 2015.;

8. Hamidov J.A. Technology of creation and application of modern didactic means of teaching in the training of future teachers of vocational education: Abstract of the doctoral dissertation (DSc) on pedagogical sciences. -Tashkent, 2017;

9. Toshov M.J. Ensuring the content and structure of pedagogical integration in the educational process of pedagogical colleges. Diss. ... Ped. (PhD) - Tashkent, 2012. - 139 p .;

10. Abduquddusov 0 . An integrated approach to vocational education teacher training. T .: Fan, 2005, - 157 p .;

11. Jumaniyozova M. Integrated knowledge in teaching physics and methodological bases of their use (on the basis of physics and astronomy teaching materials): Ped.fan.nomz. written dissertation for academic degree. avtoref. -T .: 2007. -18 p.

12. Мавлонова Р.А. Бошланғич таълимнинг интеграциялашган педагогикаси. Методик қўлланма. -Т.: ТДПУ, 2005. -109 б.

13. Bakhromovich, S. I. Development trends and transformation processes in academic mobility in higher education in Uzbekistan and the world.

14. Bakhromovich, S. I., \& Lutfillo, M. (2021). Development of ecological culture in 
CURRENT RESEARCH JOURNAL OF PEDAGOGICS 2(6): 32-37, June 2021

DOI: https://doi.org/10.37547/pedagogics-crjp-02-06-08

ISSN 2767-3278

(C)2021 Master Journals

Crossref dof 81 Google

Accepted 11thJune, $2021 \&$ Published $16^{\text {th }}$ June, 2021

students in the process of education of history of Uzbekistan. 